\title{
Female Gender Identity in the Adaptation of Disney Live-action Film Mulan
}

\author{
Xu Qingli*, Shi Ying \\ Foreign Languages Department, Zhanjiang Preschool Education College, Zhanjiang, China \\ Email address: \\ suexu7988@aliyun.com(Xu Qingli), shiying06140614@126.com(Shi Ying) \\ ${ }^{*}$ Corresponding author
}

\section{To cite this article:}

Xu Qingli, Shi Ying. Female Gender Identity in the Adaptation of Disney Live-action Film Mulan. English Language, Literature \& Culture. Vol. 5, No. 3, 2020, pp. 112-115. doi: 10.11648/j.ellc.20200503.16

Received: August 21, 2020; Accepted: September 2, 2020; Published: September 21, 2020

\begin{abstract}
The Disney's 2020 live-action Mulan is remade from its 1998 animated one whose box office globally grossed 304 million. Both movies are based on Chinese "The Ballad of Mulan" that a young woman disguised as a man to join the army about 1500 years ago. The 2020 Mulan movie is adapted to strengthen Mulan's motto "loyal", "brave" and "true" as a warrior, spill Li Xiang into Chen Honghui and Master Tung, replace Mushu with phoenix, and create two female role: Mulan's sister Xiu and a witch Xianniang for views of new era from the 1998 animated film. These changes are analysed from a perspective of female gender identity to conclude that "loyal", "brave" and "true" motto will push women to be engaged in social fairs and take more social responsibilities, omission of Li Xiang is helpful for women to break their hidden Cinderella complex, Phoenix, a female symbol, rather than a dragon, a male, is better to be Mulan's guardian, and Xianniang, the villain in the movie, is pessimistic for women to take their place in the world, showing her power as a woman in a negative way. These adaptations reflect more independent gender identity of females.
\end{abstract}

Keywords: Gender Identity, Mulan, Female

\section{Introduction}

Television, radio, newspapers and films have long been recognized as key players in society: helping to define people's sense of taken-for-granted normality [1]. Mass media such as TV and films are also often identified as an important source of 'role models'[2]. Disney's status as a producer and distributor of the genre of animated fantasy and children's film often results in audience members placing its products in a safe niche above reproach or interrogation and Disney princess series have influences in gender perception of females [3], which usually refers to society's concept of how men and women are expected to act and how they should behave [4-5]. In oriental and western tradition, masculine roles are usually associated with strength, aggression, and dominance, while feminine roles are usually associated with passivity, nurturing, and subordination [6], which is reflected in the early Disney movies. According to Amy M. Davis [7], since the mid-1930s, female characters had begun to take on a more central role at Disney productions; the usual perception of the Disney films from 1930 s to 1960 s were made up almost solely of not just fairy tale princesses, but specifically blonde-haired, blue-eyed, "all-American"types and female roles and had gone on much fewer sustained adventures and been more framed within domestic settings throughout their films; yet, the heroines from 1970 s to 1980 s did not sit passively pining for her lover to find and rescue her, and the hero was not an all-conquering warrior or romantic dream-prince. Films of this era focused upon adventure and team work. Indeed, in the United States of the era, the notion that men and women - and certainly boys and girls - could work together on equal terms was finally entering into mainstream thinking, certainly the portrayal of a girl working equally with a boy would have been seen as both positive to children. However, ideas such as child-care facilities, equal pay for equal work, women working in leadership positions, and the importance of female contributions both to the workplace and American life as a whole did not enter into the social and cultural lexicon, 
and did not become a secure part of the majority's accepted value system until the mid- to late-1990s - when stronger, tougher women had begun to appear, both within Disney films and in the larger arena of Hollywood cinema and at that time, the animated Mulan was made and got global box office of $\$ 300$ million in 1998 .

The Disney 1998 Mulan movie is based on Chinese "The Ballard of Mulan" [8] written in the Northern and Southern Dynasties about 1500 years ago. A dutiful daughter named Hua Mulan from a family without a son of age, takes the place of her crippled father, a veteran warrior, when a draft order from the Emperor obligates each family to provide one able male to raise an army to defend the kingdom from northern invaders. Mulan, a brave and able horsewoman, leaves her village posing as a man and joins the army, having a long journey to be a skillful and valorous soldier, eventually becoming a battle-hardened warrior. After 12 years of service she gains favor with the Emperor, and a grant of a wish. So she requests only a horse to return to her family, donning her old clothes and revealing the secret she is a woman to the surprise of her comrades.

The 2020 version is live-action movie remade from the 1998 animated one. The animated Mulan is musical and directed by Barry Cook and Tony Bancroft, two males, while the live-action Mulan is not musical and directed by Niki Caro, a female, as more women begin to move into such key movie-making roles as producer and director. Both movies have the same story, but the new one is adapted in putting weight on warriors' motto "loyal", "brave" and "true", spilling Li Xiang in the 1998 movie into Chen Honghui and master Tung in the 2020 Mulan, replacing dragon Mushu with a phoenix and creating new female roles Xiu and Xianniang. These changes reflect the development of female gender identity with the time.

\section{Analysis of Adaptations}

The Disney princess franchise is a powerful force in the lives of young girls. Yet not all of Disney's female protagonists are technically princesses or enjoy a princess-like existence. Instead, Mulan eithor of 1998 or 2020 made by Disney is portrayed as a strong country girl different from the early Disney princess and is moved away from previously common elements, like female passivity [9-11]. In spite of winning acclaim for new protagonists that purportedly model feminism, Disney does not achieve gender parity in its portrayal of the animated heroine Mulan of 1998. Disney live-action Mulan reportedly carries a more than \$290 million dollar price tag, which makes it one of the most expensive movies ever made. The 2020 Mulan has made some changes when remaking from the 1998 animated film. Some changes are welcomed from female viewers and thought to push the construction of social gender identity of females.

\subsection{From Xiu to Mulan}

Both movies attach importance to Mulan's growth from a country girl to a real warrior who takes responsibility of saving the emperor, the army and the country. But the live-action adds weight to Mulan's ego development. There are three phases of Mulan's growth in the 2020 film. At first Mulan makes efforts to be a woman like her sister Xiu, a newly created role in the live action, who is "quiet", "demure" and "graceful" and can bring honor to the family, so she puts on make-up and meets matchmaker with her mother. Unfortunately, a spider ruins all efforts. Then, Mulan takes her father's horse and sword to join the army where she met Chen Honghui, her future lover. Mulan tells Honghui that an ideal woman is courageous, smart and has sense of humor. A soldier named Yao says "Mulan is not describing a woman, she's describing a man". So at the second phase, Mulan tries to be a "courageous", "funny" and "smart" woman which is not biologically or socially female, but usually marked as male characteristics. "Sense of humor" or "funny" is a westernized rather than Chinese virtue. And at the third phase, Mulan makes efforts to be a "loyal", "brave" and "true" woman warrior who can bring honor to her family. She is loyal to her country and brave in the training and battlefield. Meanwhile she is struggling that she tells a lie that she is a man. But she drapes her hair as a woman when saving the emperor, the army and the country and finally Mulan's father Hua Zhou speaks of Mulan to their ancestors, stating that she is "the great warrior Mulan: the loyal, the brave, the true."

Warriors' motto "loyal", "brave" to which Mulan manages to fit action originate from Confucianism and "true" is not directly mentioned, but it is closely related to virtues such as being honest that Confucianism calls people to adhere to. The Chinese characters “忠” “勇” “真” for "loyal, brave, and true" appear on Mulan's sword on the movie post. Loyalty usually refers to be loyal to the country, being brave means to be brave in battlefield or in life and being true is true to oneself and others. They are virtues that Confucianism advocates men to obey. As a warrior, often a male warrior, being loyal to their country and fighting bravely for their country will bring honor to their family while being "quiet, demure and graceful" like Xiu brings honor to a woman's family, as Mulan's mother said, "A daughter brings honor through marriage." "Quiet, demure and graceful" are women virtues first mentioned in "Woman's Commandments" written by Ban Zhao (45-117 D.C.), a female historian and writer.

In the new film, Hua Zhou, Mulan's father, undoubtedly adored Mulan very much and was always tolerant of Mulan to be who she was. When the magistrate asked the father, "Have you no son old enough to fight?" The father answered, "I am blessed with two daughters." But the father still thought a man in a family brought honor to the family on the battlefield and warned Mulan to "learn her place". Mulan's place or a woman's place, as Hua Zhou said, was clearly taking care of her husband and children in the home like Xiu, Mulan's sister, hard working in weaving and housework to be a good wife.

Some may think that the woman's place, i.e. in the home, is outdated, but actually it is still popular that female's duty is to 
marry a man, give birth to babies and take care of the whole family. It is still hard for women to cover the journey from Xiu to Mulan. Days ago, Yang Liping, a successful talented Chinese dancer with no children, shared a video of her daily life online and was commented by a young woman, "A woman's biggest failure is that she has no children. The so-called living your own life is deceptive. Now you (in your fifties) look like a 30-year-old woman, but when you are 100 years old, can you still keep your appearance of 30? Even if you are beautiful and excellent, you can't escape from time. When you are 90 years old, will you get your happiness without children and grandchildren?" Even though the female netizen was criticized by many netizens of different genders and ages, the comment still got more than 10,000 thumbs-up. Therefore, women still need encouraging to be out of their home and take more social responsibilities to the country or the world. In the 1998 version, Mulan teaches girls what constitutes a happy ending: going home to fulfill domestic duties. The movie does not conclude with her military victory. Instead, she returns home to emotionally embrace her father and then presumably secures a spouse. We happily see that Mulan accept the position as an female officer in the Imperial Guard at the ending episode of 2020 version. Mulan in the live-action movie has better "role model effect" to positively improve women to empower themselves politically and socially, and then correspond with increased numbers of women in senior roles in the labour market and other fields.

\subsection{Phoenix VS Dragon}

In the 1998 Mulan, the dragon Mushu protects Mulan as her guardian and has stayed with her since she left home; in the 2020 film, a phoenix replacing the dragon helps Mulan whenever she is in trouble, and flies away satisfied when Mulan is powerful enough to protect herself even to protect others.

The phoenix (or feng huang in Chinese) and dragon are Chinese mythical animals and in China are often paired together, which symbolizes a wish for a harmonious marriage for new couple. Phoenix in China also represents female virtues such as beauty and charm, while dragon represents male feature like power. And because of this, the dresses worn by the ancient emperors in China are often decorated with a picture of dragons and the phoenix was also accorded a similar significance to empresses. Phoenix Nirvana originated from eastern Buddhism, and is also related with western culture "a phoenix from the ashes", reflecting phoenix's persistence and strength. At the beginning of the 2020 movie, the father also told the daughter, "Failure is not fatal, Mulan. This is the lesson of the Phoenix. What matters is that each day you rise up and continue. The phoenix will watch over you."

Actually, phoenix or 'feng huang' incorporates the notions of feng, a male bird and huang, a female bird, therefore according to that logic, the phoenix is actually a symbol of the combination between masculinity and femininity, or Yin-Yang. In the new movie, Hua Zhou, Mulan's father told her, “...she (the phoenix) is half male and half female...she is both beautiful and strong." A phoenix is a better choice than a dragon as Mulan's guardian and supporter and contributes to constructing female identity that women may look graceful, but has persistence and power.

\subsection{Chen Honghui VS Li Xiang}

In the Disney live-action Mulan remake, the character of $\mathrm{Li}$ Xiang, who is a captain in the Chinese army and Mulan's commanding officer, and ultimately falls in love with her in the 1998 Disney animated film Mulan, is omitted and split into two characters. One is Commander Tung who serves as her surrogate father and mentor and the other is Chen Honghui who is Mulan's equal in the squad. The change arouses arguments. The producer of the remake movie gives to Collider an explanation that "in the time of the \#MeToo\# movement, having a commanding officer that is also the sexual love interest was very uncomfortable and we didn't think it was appropriate." But this explanation does not appease some fans who feel Li Xiang was removed to avoid depicting his perceived bisexuality. This paper will not discuss the reasons for the omission of Li Xiang, but the positive instructions to some women who have Cinderella complex, which was coined by C. Downing in her 1982 book of the same name for what she describes as woman's unconscious desire to be taken care of by others, based primarily on a fear of independence, often coupled with a need to be rescued by an outside force-e.g., a prince [12]. This is an excellent move because today's Mulan doesn't need that "prince element" to help Mulan see her worth. It is an old story trick to have a prince to rescue a princess out of mess and still popular in a hidden way.

I had a survey of 90 female college students. One question is "Should husbands earn more than wives?" More than 30 percent young women choose "Yes". It is not a low percentage of women who has hidden Cinderella complex. Certainly, they do not really have love affairs with or marry a prince, but hope to have a "white horse prince" who earns more, has higher social position or more successful course than themselves, which I call hidden Cinderella complex.

Although education attainment as well as health and survival enjoy much closer to parity $(96.1 \%$ and $95.7 \%$ respectively) reported in global gender gap report in 2020, one important area of concern is that of economic participation and opportunity. This is the only dimension where progress has regressed. Here, the figures are sobering, with a deteriorating situation forcing gender parity to a lowly $57.8 \%$.

The report highlights the primary reasons for this: women have greater representation in roles that are being automated; not enough women are entering professions where wage growth is the most pronounced (most obviously, but not exclusively, technology). However, it is more important to break the hidden Cinderella complex that husbands should earn more than wives. If women think men should earn more than women, how can they actively make efforts to narrow the gender parity in earning?

Therefore, being an independent woman with no Cinderella complex, it is better for Mulan to work and grow with her comrade-in-arms Chen Honghui rather than her superior Li Xiang. 


\subsection{Xianniang VS Mulan}

Xianniang is a witch, a newly created role, who possesses special powers in the 2020 live-action movie. As the story unfolds, Xianniang learns that she has more in common with her young adversary Mulan than she realizes. In a male world, they find "The more power I showed, the more I was crushed." Woman's power can't be admitted in a male world. Xianniang's own people have shunned her. As white snow princess has an evil stepmother in other Disney's princess movies, Xianniang is also a villain in the Mulan movie. Unlike stepmothers in Disney's princess movies, Xianniang makes use of her special powers not to be the most beautiful or powerful woman in the world, but to take her place so that she can be accepted as a powerful woman. Compared to Mulan, Xianniang is pessimistic, she says, "They (men) will not listen to you! It will always be a man's army". Mulan is more optimistic and determined and finally succeeds to achieve her place as a woman in the army.

\section{Conclusion}

When the woman director Niki Caro was interviewed why she chose Liu Yifei to act as Mulan, she said, "She kicks ass with the sword and she's incredibly beautiful, but she's also really handsome. As a guy, she fits in." Mulan has the features of a woman and a man, which is strengthened in the live-action Mulan movie. The movie focuses on the growth of Mulan from a country girl in a male world to a loyal, brave and true warrior which often characterizes a man. A phoenix rather than a dragon is her guardian and flies away when Mulan grows powful enough to protect herself. Chen Honghui, her comrade-in- arms, is her lover and they work and develop together rather than a superior in professional field helps her. Xianniang, a powerful witch, is tragic when she wants to take her place in the world in a negative way. All these changes in the live-action Mulan movie contributes to building a more independent female identity in the modern world and new Mulan makes the right way.

\section{Acknowledgements}

This research was supported by the 2019 Guangdong Youth Innovative Talents Project "A Study on the English Translation of Chinese Children's Literature in the New Century from the Perspective of Systematic-functional Linguistics" (2019GWQNCX156); 2018 Zhanjiang Preschool Education College Project "A Comparative Study on English and Chinese Children's Picture Books from the Perspective of
Cognitive Linguistics "(ZJYZZD201802)

\section{References}

[1] Eldridge, J., Kitzinger, J. and Williams, K. (1997) The mass media and power in modern Britain. Oxford: Oxford University Press.

[2] B. Tammy and J. Kitzinger. (2008) Promoting women in the media: The role of SET organisations and their science media communicators, Research report series for UKRC No. 4. Bradford: UK Resource Centre for Women in Science, Engineering and Technology.

[3] Brocklebank, L. Disney's "Mulan"—-the "True" Deconstructed Heroine? Marvels \& Tales, Vol. 14, No. 2 (2000), pp. 268-283. Wayne State University Press.

[4] FAO, Rome (Italy). Women, Population Div. eng (1999). Agricultural Censuses and Gender Considerations - Concept and Methodology. Rome, Italy: Food and Agricultural Organization of the United Nations. available online.

[5] Little, W., McGivern, R., Kerins, N. (2016). Introduction to Sociology - $\quad 2^{\text {nd }} \quad$ Canadian Edition. https://opentextbc.ca/introductiontosociology2ndedition/chapt er/chapter-12-gender-sex-and-sexuality/

[6] Prentice, D. A. and E. Carranza (2002). What Women and Men Should Be, Shouldn't Be, Are Allowed to Be, and Don't Have to $\mathrm{Be}$, the Contents of Prescriptive Gender Stereotypes. Psychology of Women Quarterly, Volume 26, Number 4, December 2002, pp. 269-281 (13). Wiley-Blackwell (publisher).

[7] Davis, A. M. (2007) Good girls and wicked witches: Women in Disney's feature animation. John Libbey Publishing.

[8] The Flowering Plum and the Palace Lady: Interpretations of Chinese Poetry (The Ballard of Mulan By Han H. Frankel, Yale University Press, 1976.

https://kevinjamesng.com/2015/06/22/finding-mulan-the-balla rd-of-mulan/

[9] CHEU, J. (ed) (2013) Diversity in Disney Films: Critical Essays on Race, Ethnicity, Gender, Sexuality and Disability.

[10] Dunders, L., \& Streiff, M. (2016). Reel Royal Diversity? The Glass Ceiling in Disney's Mulan and Princess and the Frog. Societies 2016, 6, 35; doi: 10.3390/soc6040035 www.mdpi.com/journal/societi

[11] Cook, J., \& Hasmath, R. (2014). The discursive construction and performance of gendered identity on social media. Current Sociology 2014, Vol. 62 (7) 975-993 sagepub.co.uk/journals Permissions.nav.

[12] Dowling, C. (1981). The Cinderella Complex: Women's Hidden Fear of Independence/. 